DOI https://doi.org/10.18551/rjoas.2017-11.31

\title{
THE HOUSE FACILITATION FOR THE LOW-INCOME COMMUNITY: A STUDY ON THE SELF-RELIANCE HOUSING STIMULUS PROGRAM
}

\author{
Utomo Fajar Cahyo \\ Faculty of Economics, Universitas Krisnadwipayana, Indonesia \\ E-mail: fajarcutomo@gmail.com
}

\begin{abstract}
There have not been many studies examining the success of the Self-Reliance Housing Stimulus Program in improving the quality of habitable houses from the perspective of the low-income communities. This study tries to explore the success of the program in improving the quality of the habitable houses before and after getting the support by surveying 388 lowincome households in cities and regencies located in the Central Java Province. The result of the research shows that with the program has helped the low-income people to improve the quality of their houses. The increase can be seen in the physical factors of the building, the environmental, and the health factors.
\end{abstract}

\section{KEY WORDS}

Habitable house, low-income communities, self-reliance housing stimulus.

Based on the mandate of the 1945 Constitution and the Article $28 \mathrm{H}$ of the Amendment to the 1945 Constitution, the right to adequate housing is one of the basic rights of the people and therefore every citizen shall have the right to live and receive a good and healthy living environment. In addition, home is also a basic human need in improving the dignity and quality of life and livelihood as well as a personal reflection in the effort to improve the standard of living as well as to form the character and personality of the nation. Home is also the smallest environment that serves as a place where humans interact in the process of growing up. Because of its fundamental nature, every year there is always an increase in the needs of housing along with the increase of population. The orientation of housing and settlement development is focusing on providing housing with such low funds. The number of rented houses in 2016 amounted to $8.51 \%$ and self-owned houses amounted to $82.58 \%$ (BPS, 2017).

The 1945 Constitution mandates that the right to adequate housing is one of the basic rights of the people and that the state through the government shall provide assistance to people who have not been able to own a house or already have a house but not fulfilling the standard of adequate housing. According to Mungkasa (2011), the condition allows the government to have self-reliance housing programs as one of the spearheads of the fulfillment of human rights. However, many things must be done to make the programs run effectively and efficiently. A comprehensive scenario, from the paradigm, basic principles, policies, strategies, road maps, to the funding and human resource, needs to be agreed upon by all stakeholders. The programs by the government of Indonesia in fulfilling the needs of habitable housing are run by the Ministry of Public Works and Housing, one of which is the Self-Reliance Housing Stimulus Program dedicated to Low-Income Communities. The program has been in implementation since 2009 until now.

The program is in the form of social assistance to encourage the low-income communities to build habitable housing and/or healthy and safe environments. This assistance is a leverage of community self-reliance in various forms either in the form of additional funds, labor, or other support. It is hoped that this assistance can foster selfreliance initiatives for their own good as well as beneficial for the relatives, neighbors, and the surrounding environment, so the support can be used to complete the construction or improve the quality of houses.

The fulfillment of the needs for houses mandated in the 1945 Constitution is set forth in the National Long Term Plan of the Republic of Indonesia from 2015 to 2019 in the Self- 
Reliance Housing Stimulus Program, where the target to be completed by 2019 is $1,750,000$ housing units on the construction of new self-reliance houses of 250,000 units and an increase of self-reliance housing quality by $1,500,000$ units. In 2015 , the program is planned to build 20,756 new housing units and improve the quality of 61,4489 old housing units (the Ministry of Public Works and Housing, 2016). The following is the realization of the program in 2015 in 31 provinces of Indonesia.

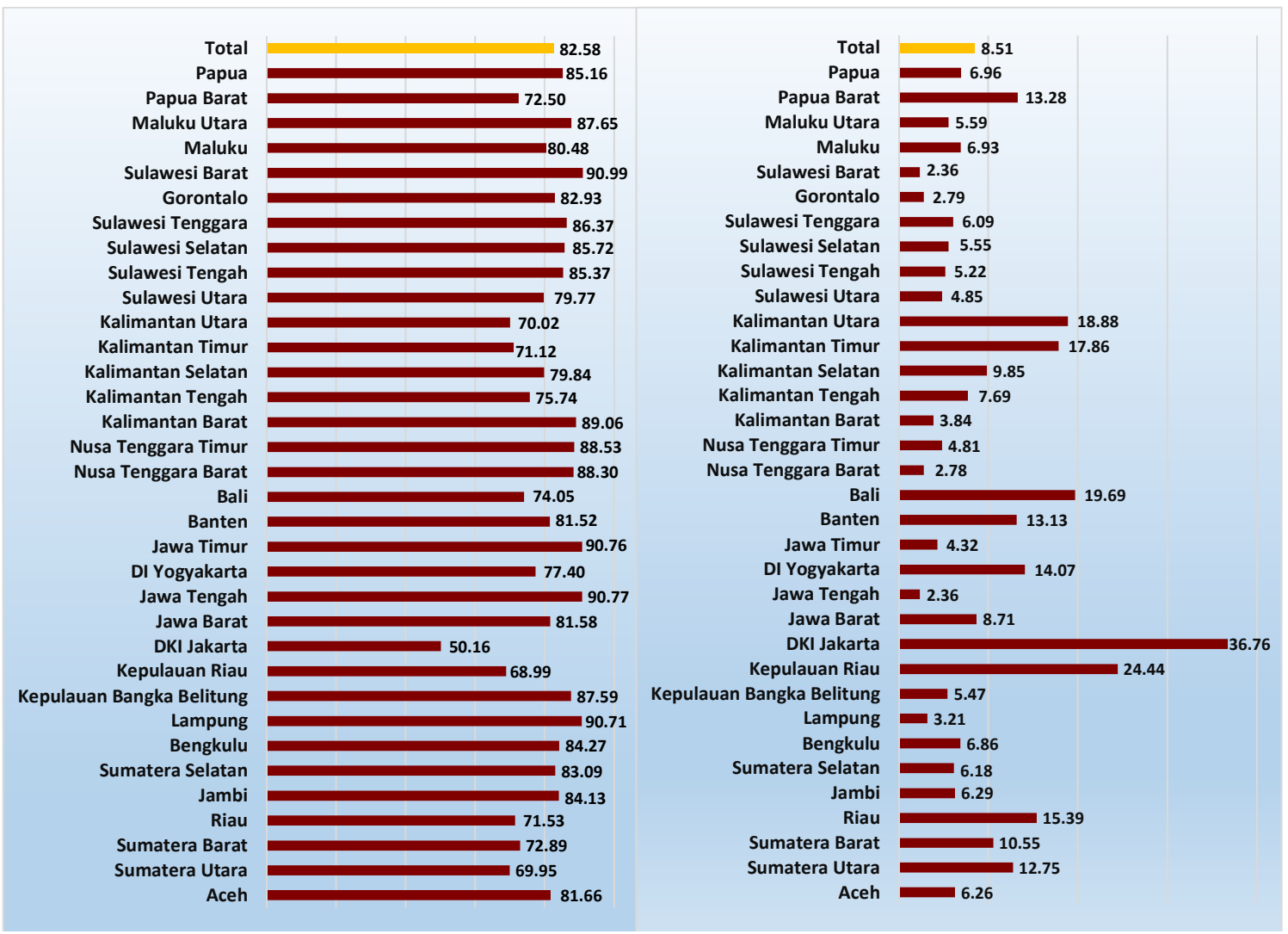

Figure 1 - Percentage of Households

by Provinces and the Status of Self-Owned

Houses, 2016 (Source: BPS, 2017)

Figure 2 - Percentage of Households

by Provinces and the Status of Rented Houses, 2016 (Source: BPS, 2017)

Table 1 - The Number of New Housing Units Built and Old Housing Units Improved by the Self-Reliance Housing Stimulus Program in 2015

\begin{tabular}{|c|c|c|c|c|}
\hline \multirow{2}{*}{$\mathrm{n} / \mathrm{n}$} & Province & Quality Improvement & New Houses Built & Total \\
\cline { 2 - 5 } & 2 & 3 & 4 & 5 \\
\hline 1 & Riau & 410 & - & 410 \\
\hline 2 & Sumatera Utara & 2,289 & - & 2,289 \\
\hline 3 & Aceh & 1,605 & 2 & 1,605 \\
\hline 4 & Sumatera Barat & 4,154 & - & 4,156 \\
\hline 5 & Kepulaian Riau & 239 & 1,159 & 239 \\
\hline 6 & Lampung & 1,592 & 377 & 1,419 \\
\hline 7 & Bengkuli & 1,042 & 136 & 1,900 \\
\hline 8 & Sumatera Selatan & 1,764 & 542 & 1,145 \\
\hline 9 & Jambi & 603 & 3,235 & 9,068 \\
\hline 10 & Jawa Barat & 5,833 & 826 & 839 \\
\hline 11 & Banten & 13 & 1,322 & 13,736 \\
\hline 12 & Jawa Tengah & 12,414 & 1,746 & 2,321 \\
\hline 13 & D.I. Yogyakarta & 575 & 1,617 & 6,660 \\
\hline 14 & Jawa Timur & 5,043 & 9 & 3,173 \\
\hline 15 & Kalimantan Barat & 3,164 & 3 & 1,745 \\
\hline 16 & Kalimantan Selatan & 1,742 & - & 1,721 \\
\hline 17 & Kalimantan Tengah & 1,721 & 1 & 111 \\
\hline 18 & Kalimantan Utara & 110 & & \\
\hline
\end{tabular}




\begin{tabular}{|c|c|c|c|c|}
\hline 1 & 2 & 3 & 4 & 5 \\
\hline 19 & Kalimantan Timur & 488 & - & 488 \\
\hline 20 & Gorontalo & 1,437 & 1,616 & 3,053 \\
\hline 21 & Sulawesi Selatan & 2,173 & - & 2,173 \\
\hline 22 & Sulawesi Tengah & 3,318 & 1,350 & 4,668 \\
\hline 23 & Sulawesi Tenggara & 2,974 & 218 & 3,192 \\
\hline 24 & Sulawesi Utara & 693 & 167 & 693 \\
\hline 25 & Sulawesi Barat & 1,353 & 1,080 & 1,520 \\
\hline 26 & Bali & 609 & 3,090 & 4,689 \\
\hline 27 & Nusa Tenggara Barat & 1,587 & - & 1,398 \\
\hline 28 & Maluku & 1,398 & 583 & 1,521 \\
\hline 29 & Maluku Utara & 938 & 710 & 918 \\
\hline 30 & Papua & 208 & 967 & 967 \\
\hline 31 & Papua Barat & - & 20,756 & 82,245 \\
\hline
\end{tabular}

Source: The Directorate General of The Ministry of Public Works and Housing RI, 2016.

Construction of houses along with infrastructure, facilities, and public utilities can indirectly encourage regional growth and regional economy, can support socio-cultural development as well as can provide a tangible contribution to improving the quality of housing, economic growth, poverty alleviation, and welfare improvement. Therefore, the development of a decent and healthy housing and environment is a way for the development of Indonesian human resources in the future. This study aims to see the perceptions of thelow income communities as the receivers of the assistance and see the effect of the program in improving the quality of habitable home.

\section{LITERATURE REVIEW}

In 2015, the Government of the Republic of Indondesia launched the Million Houses Program to reduce the housing backlog. One of the main targets of the Million Houses Program is the low-income communities. The success or failure of the national program is not only seen from the number of houses built, but also the accuracy of the target of providing houses, i.e. for low-income people. Based on the income levels, laborers and employees whose income is the same as the Provincial Minimum Wage are included in the low-income criterion. In addition, there are also poor people living below the poverty line, which ranks at the bottom of the low-income level.

Low-Income Communities. The low-income community, hereinafter abbreviated as LIC, based on the Act Number 11 of 2011 regarding Housing and Settlement Area, refers to those with limited purchasing power so it is necessary for them to get government support to obtain housing. Article 126 of the Act states that the government and local governments provide facilities and/or assistance in the form of finance for the construction and acquisition of public houses and self-reliance houses for these low-income people. There are 3 (three) segments of the low-income people based on the ability to access home ownership. They are the lowincome people: who already own land or houses but are unable to build/repair their houses; who are able to buy a house but of low ability to repay the mortgage; and who cannot afford to buy a house.

Habitable House. Based on the regulation of the Ministry of Public Works and Housing Number 20/PRT/M/2014 on the liquidity facility of housing finance in the framework of obtaining housing through credit for low-income people (changed by the regulation Number 20/PRT/M/2015), the target group of the Housing Credit Program represents those lowincome people with regular income and with irregular income. The income limit of the target group of the Housing Credit Program is the people with income of IDR 4 million for the landed house.

A habitable house is a house that meets the building safety requirements, th minimum adequacy of building area, and the occupant health. To meet the requirements as a habitable house, the criteria and technical requirements are as follows.

1. The Criteria: 
a. $\quad$ Meet building safety requirements, including:

- Lower structure/foundation;

- Structure/column and log (beam);

- Upper structure.

b. $\quad$ Ensure health includes lighting, air circulation and sanitation;

c. Meets minimum minimum adequacy of $7.2 \mathrm{~m}^{2} /$ person up to $12 \mathrm{~m}^{2} /$ person.

2. The Technical Requirements:

a. Safety/security factors. The house can provide a sense of security for residents and the environment around the house. The structure of the building must be in accordance with the condition of the land where the house is built, so the structure is able to withstand dead loads and live loads therein and the burden arising from certain natural conditions, such as earthquakes, wind and flood.

b. Health factors. In addition to providing a sense of security for its inhabitants, the house must also meet health standards such as caring systems and optimal natural lighting, good sanitation and the use of building materials that do not interfere with occupant health and the environment.

c. Comfort factors. The house is able to provide comfort for the inhabitants, including:

- circulation or spaces associated with the organization of relations between rooms of the house;

- temperature, the house can be used as a refuge from the hot weather during the day and cold air during the night; and

- view, the home can maintain the privacy of the occupants when performing certain activities without the worries of being seen from the outside.

\section{METHODS OF RESEARCH}

This study examines the perspective of low-income communities as the beneficiaries of the program in the sub-program of home improvement. This study was conducted in 2015 in Central Java Province as the province had the highest number of beneficiaries in 2015 . The population consisted of 12,414 people in one (1) city and twenty-one (21) regencies. The sample of the study conisted of 388 respondents, obtained using Slovin formula with a $5 \%$. The determination of sample per region (city and regency) was done proportionally because the number of beneficiaries was not the same in each city and region. The distribution of samples in each city and regency is as follows:

Table 2 - Sample Proportion According to the City and Regency in Central Java

\begin{tabular}{|c|c|c|c|}
\hline \multirow{2}{*}{$\mathrm{n} / \mathrm{n}$} & City/Regency & Population & Sample \\
\cline { 2 - 4 } & 2 & 3 & 4 \\
\hline 1 & Kota Pekalongan (city) & 50 & 2 \\
\hline 2 & Kabupaten Brebes (regency) & 921 & 29 \\
\hline 3 & Kabupaten Pemalang (regency) & 269 & 14 \\
\hline 4 & Kabupaten Batang (regency) & 433 & 21 \\
\hline 5 & Kabupaten Wonosobo (regency) & 671 & 8 \\
\hline 6 & Kabupaten Banyumas (regency) & 243 & 44 \\
\hline 7 & Kabupaten Kebumen (regency) & 1.421 & 22 \\
\hline 8 & Kabupaten Purwokerto (regency) & 28 \\
\hline 9 & Kabupaten Klaten (regency) & 705 & 14 \\
\hline 10 & Kabupaten Wonogiri (regency) & 897 & 28 \\
\hline 11 & Kabupaten Sukoharjo (regency) & 450 & 22 \\
\hline 12 & Kabupaten Sragen (regency) & 901 & 21 \\
\hline 13 & Kabupaten Tegal (regency) & 691 & 25 \\
\hline 14 & Kabupaten Pekalongan (regency) & 656 & 12 \\
\hline 15 & Kabupaten Jepara (regency) & 798 & 15 \\
\hline 16 & Kabupaten Boyolali (regency) & 371 & 12 \\
\hline 17 & Kabupaten Temanggung (regency) & 472 & 24 \\
\hline 18 & Kabupaten Semarang (regency) & 397 & \\
\hline
\end{tabular}




\begin{tabular}{|c|c|c|c|}
\hline 1 & 2 & 3 & 4 \\
\hline 19 & Kabupaten Pati (regency) & 325 & 10 \\
\hline 20 & Kabupaten Kendal (regency) & 665 & 21 \\
\hline 21 & Kabupaten Magelang (regency) & 83 & 3 \\
\hline 22 & Kabupaten Cilacap (regency) & 220 & 7 \\
\hline \multicolumn{2}{|c|}{ Total } & 12.414 & 388 \\
\hline
\end{tabular}

Source: The Directorate General of The Ministry of Public Works and Housing RI, 2016.

This data analysis technique uses a description analysis. It is used to describe or give an idea of the object under study through the data or samples collected as it is without making any analyses or conclusions. In other words, the descriptive analysis takes the problems or focuses on the problems as they are when the research is conducted; the results of which are then processed and analyzed for conclusion (Sugiono, 2009). Prior to the analysis, research instruments were tested for validity and reliability.

\section{RESULTS OF STUDY}

The initial stage of this study was testing the instrument validity to the questionnaire used. The results of the questionnaire validity test against the 16 (sixteen) items about te habitable home variables were valid. The value of $r$-count was greater than the r-table for the whole items. Furthermore, after the validity test, the reliability test with alpha $1 \%(\mathrm{~N}-2)$ was performed. The result was that the correlation coefficient value greater than the r-table value $(0.877>0.148)$; thus, the instrument was significantly reliable. To capture the perspective of respondents, questionnaires with closed questions were used. There were sixteen (16) statements with A-D alternatives.

Physical Factors of the Building. This relates to the level of house damage before receiving the assistance. There were 283 or $73 \%$ of low-income people. The house damage before receiving assistance reached $26 \%-50 \%$. There were 89 people $(23 \%)$ experienced $<25 \%$ house damage, and 16 people exepereinced $51 \%-75 \%$ house damage. After the program, $206(53 \%)$ people stated that their house was much better compared to the previous condition, $167(42 \%)$ people stated that their house was better, and 19 (5\%) people stated that their house was quite good.

Related to the width of the house before getting assistance, as many as $171(44 \%)$ people had about $51 \mathrm{~m}^{2}$ to $75 \mathrm{~m}^{2}, 167(43 \%)$ people had about $37 \mathrm{~m}^{2}$ to $50 \mathrm{~m}^{2}, 43(11 \%)$ people had $>76 \mathrm{~m}^{2}$, and $8(8 \%)$ had a total area of $>36 \mathrm{~m}^{2}$. The addition of house building area after the program by $25 \%$ was experienced by $237(61 \%)$ people, by $50 \%$ was experienced by 147 (38\%) people, and by $75 \%$ was experienced by $4(1 \%)$ people.

In terms of improving the quality of houses, the program requires the beneficiaries to pay attention to building materials used, such as the roof. The material previously used by $241(62 \%)$ people was asbestos, $78(20 \%)$ people used rumbia, $66(17 \%)$ people used zinc corrugated roof, and $4(1 \%)$ people used the roof tile. After the program, $233(60 \%)$ people used the roof tile. As many as $85(17 \%)$ people still used asbestos, and the rest70 $(18 \%)$ people used zinc corrugated roof.

The next material to change was the wall. Wall materials used by the community were mostly wood. A total of $287(74 \%)$ people still used woods for the walls, 16 (4\%) people used concrete, $31(8 \%)$ used tarpaulins, and $54(14 \%)$ people used other types of materials. After the program, $198(51 \%)$ people used concrete, $120(31 \%)$ used woods, and used $19(5 \%)$ tarpaulins.

The program also required beneficiaries to use appropriate flooring materials for the improvement of quality of life. Currently, as many as $287(74 \%)$ people used no tiles, 89 (23\%) used cement flooring, and $12(3 \%)$ people already used ceramics. The change after the program was the use of the ceramic material by $241(62 \%)$ people and cement flooring by $147(38 \%)$ people.

Health Factors. The home environment health in this study is based on Ministerial Regulation Number 06 of 2013 on Guidelines for Implementation of Self-Reliance Housing Stimulus Program. Article 3 states that the type of assistance provided may be the 
construction of infrastructure, facilities, and utilities attached to the house, among others, sources and networks of clean water, bathrooms, landfills.

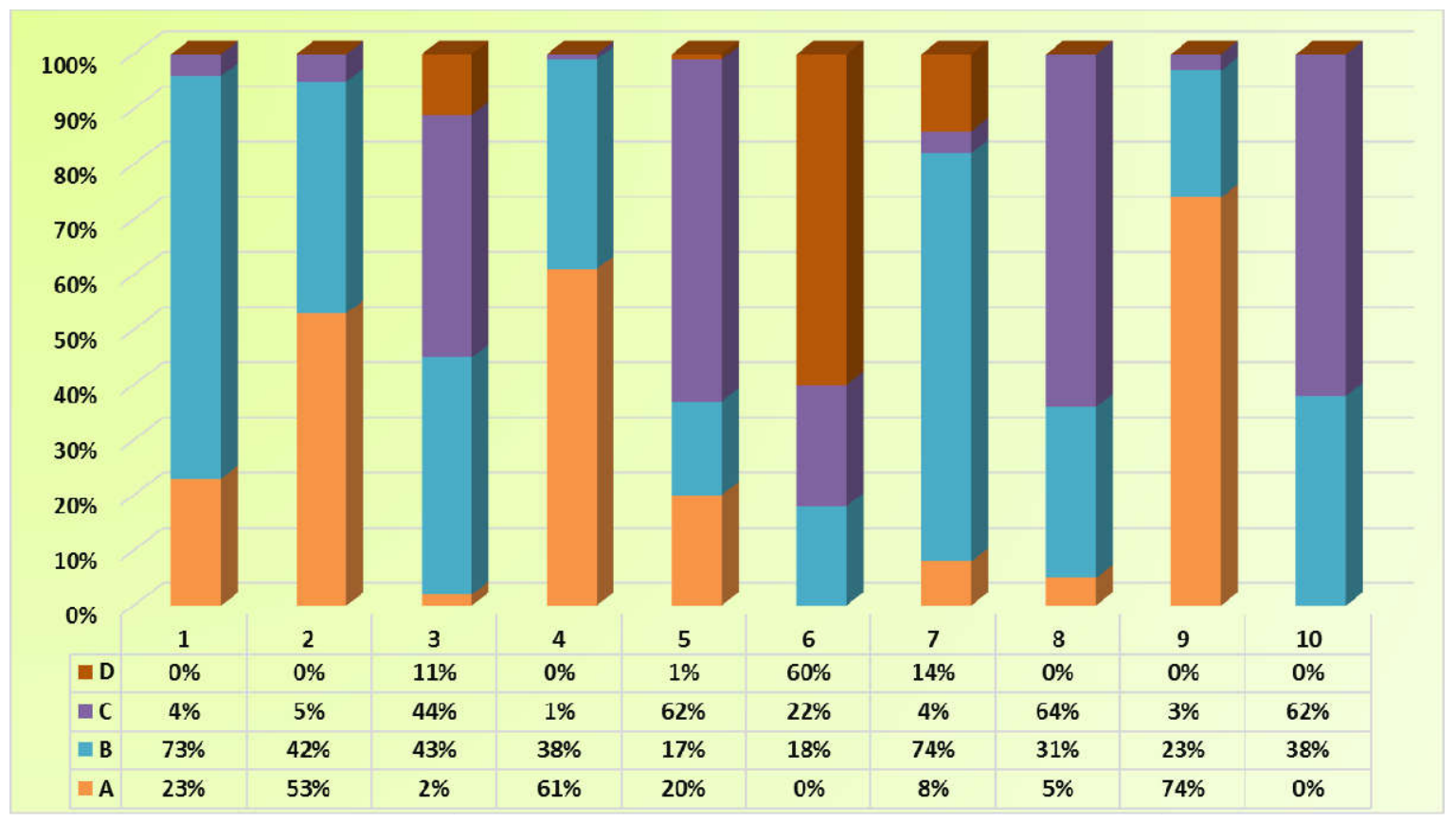

Source: Primary Data Processed 2017.

Figure 3 - The Perspective of the Low-Income Communities on the House Improvement Sub-Program through the Self-Reliance Housing Stimulus Program (Physical Building Factor)

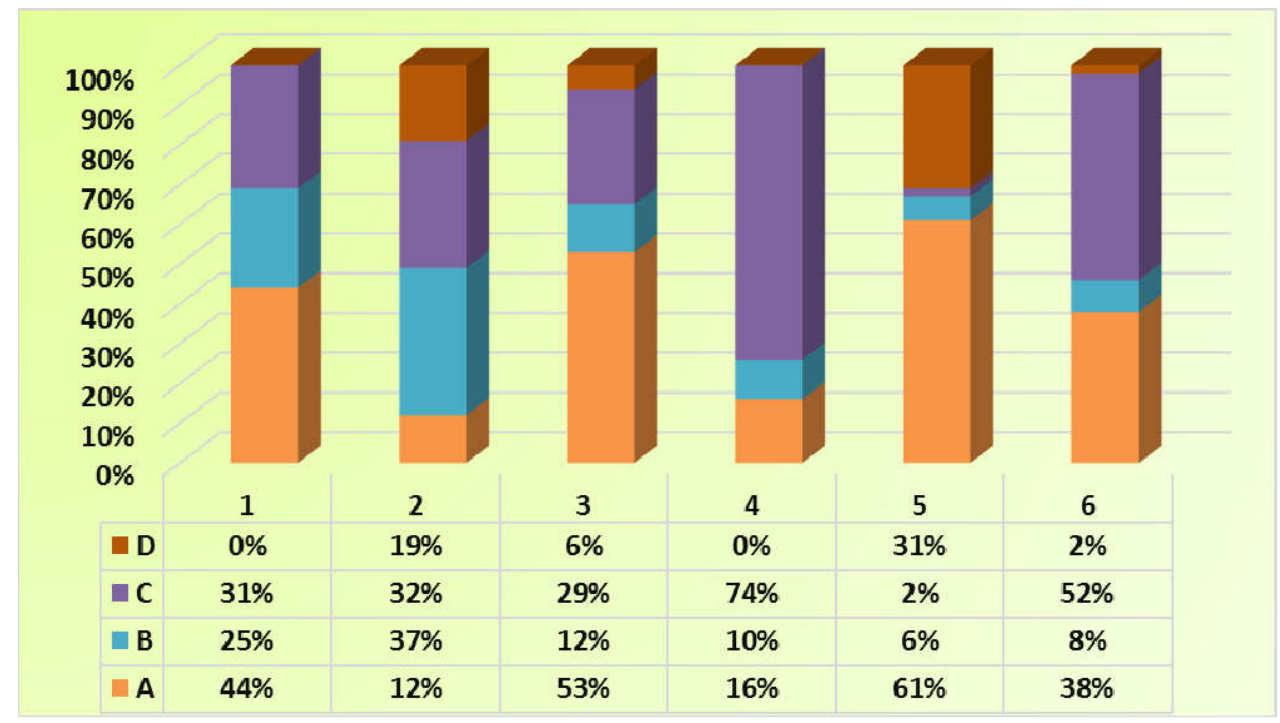

Source: Primary Data Processed 2017.

Figure 4 - The Perspective of the Low-Income Communities on the House Improvement Sub-Program through the Self-Reliance Housing Stimulus Program (Health Factor)

The surrounding environment of the houses of the low-income communities is not so healthy. For drinking water infrastructure, 171 (44\%) people utilized river water, $120(31 \%)$ people used drilled well water, and $97(25 \%)$ people used spring as the drinking water source. After the program, 144 (37\%) people already used springs as the drinking water source, $124(32 \%)$ people still used drilled well water, and $47(12 \%)$ people kept on using river water as a the source of drinking water. Some communities have also realized the 
importance of healthy drinking water sources; thus, a large number of people already used the water provided by the local water company.

As many as $206(53 \%)$ people used public toilets. A total of $47(12 \%)$ people still used the river, 113 (29) people used water closet (WC) in their house, and as many as $23(6 \%)$ used other facilities. The real change after the program was the increase in the number of people using private water closet (WC) as many as $287(74 \%), 62(16 \%)$ used the public toilets, while others still used the river.

Another environmental health factor is related to landfills. Before the program, most of the people preferred to burn the garbage. Based on the result of the research, there were $237(61 \%)$ people burnt their garbage, $120(31 \%)$ people dumped the garbage in the river, 23 $(6 \%)$ buried their garbage, and only $8(2 \%)$ people dumped garbage in a landfill around their house. Following the program, $202(52 \%)$ people used the landfill, $147(38 \%)$ people still burnt their garbage, $31(8 \%)$ people buried their garbage, and the real impacts arising from the program was a lower number of people throwing their garbage in the river, which was only $8(2 \%)$ people.

\section{DISCUSSION OF RESULTS}

Based on the results of the analysis, it can be seen that from the perspective of lowincome communities receiving the program, there has been an increase in the quality of the habitable house building from the aspects of physical factors. Before the program, the level of damage was $26 \%$ to $50 \%$, yet after the program, the condition of the house has been very good. The house building area after the program has increased by $25 \%$. The roofing material has been changed to tiles, the walls have been changed to concrete, and almost all floors have already used ceramics.

Based on the results of the analysis, it can be seen that from the perspective of lowincome communities receiving the program, there has been an increase in the quality of the habitable house building from the aspects of the health of the surrounding environment. The people mostly nowadays have used drilled well water. Before the program, most of them used the river water and springs as a source of drinking water. In addition to drinking water, after the program, the community already has had a water closet (WC) inside the house, where previously most of them used the river as the toilet. The other benefit of the program is that the community now has a garbage dump in each house, so they do not dispose household garbage in the river or by burning and burying.

The idea that 'occupant control' contributes to the impacts of the habitable home has been proven. The idea is supported by Huchzermeyer and Omenya (2004), comparing the independent self-reliance houses with non-independent self-reliance houses (let alone government intervention too strong). Independent self-help house is better and wider and grows much better. This is also supported by the high sense of belonging by the residents that result in their high satisfaction. Based on the results of research conducted by Carmon and Gayrieli (1987), comparing self-reliance and non-self-reliance housing, the first housing produced more qualitative homes, better neighborly relationships, and more satisfied residents. In addition, the community is also encouraged to maintain its environmental conditions. This condition is achieved with only a small government cost compared to nonself-reliance housing (Ntema, 2011). Habitable home conditions can have an impact on improving the condition of the economy of its inhabitants. It is evident that improved family economic conditions encourage gradual improvement of housing conditions (quality and extent) (Pugh, 2001). Nevertheless, the occupant control can encourage residents to ignore the economic difficulties they face and still improve the quality of their homes.

\section{CONCLUSION}

From the study, it can be concluded that the Self-Reliance Housing Stimulus Program of the Ministry of Public Works and Housing is able to give a direct impact on the improvement of the quality of habitable home. The improved quality is in the physical quality 
and home environment health. The success of the program cannot be separated from the support and active participation of the low-income communities. The form of support is selffunding and the participation of family members and beneficiary groups in the house building process.

Theoretically, this study can be used as a reference about the Self-Reliance Housing Stimulus Program. In addition, it can also increase knowledge and insight on how to improve the quality of habitable home for the low-income people). The Ministry of Public Works and Housing must manage the program well to realize what has been mandated in the 1945 Constitution and Article $28 \mathrm{H}$ of the amended 1945 Constitution in which each citizen is entitled to live and get a good and healthy living environment .

\section{LIMITATION AND FUTURE STUDY}

This study does not include all the criteria and technical requirements of a habitable house determined by the Indonesian government. Criteria not been included in the study are (1) health factors including optimal air and natural lighting, air circulation and sanitation; (2) safety/security factors including the structure of the building that must be in accordance with the condition of the land where the house is built, so the house is able to withstand dead loads and live loads as well as the burdens arising from certain natural conditions such as earthquakes, wind, and flood; (3) comfort factors such as circulation or movement of space, temperature, and so forth.

This study also needs further development as to calculate the amount of leverage that occurs along with the self-reliance housing program to improve the quality of the houses. As it is known, the self-reliance housing is designed for residents to develop their own houses in the long term. This is in accordance with Turner's idea that a house should be viewed as a verb and not a noun. A house should be regarded as a process (Turner, 1976), so it will never finish but will continue to grow. Similarly, when observations are made, they are not recommended to be instantaneous (snap shot) but in a long time.

\section{REFFERENCES}

1. Undang-Undang Dasar Negara Republik Indonesia Tahun 1945 pasal $28 \mathrm{H}$ ayat 1. www.hukumonline.com

2. Undang-Undang Republik Indonesia nomor 11 Tahun 2011 tentang Perumahan dan Kawasan Permukiman. www.hukumonline.com.

3. Peraturan Menteri Pekerjaan Umum dan Perumahan Rakyat Republik Indonesia nomor 06 Tahun 2013 tentang Pedoman Pelaksanaan Bantuan Stimulan Perumahan Swadaya. www.birohukum.pu.go.id.

4. Peraturan Menteri Pekerjaan Umum dan Perumahan Rakyat Republik Indonesia nomor 20 Tahun 2015 tentang perubahan atas peraturan menteri pekerjaan umum dan perumahan rakyat nomor 20 tahun 2014 tentang Fasilitas Likuiditas Pembiayaan Perumahan dalam Rangka Perolehanrumah Melalui Kredit/Pembiayaan Pemilikan Rumah Sejahterabagi Masyarakat Berpenghasilan Rendah. www.birohukum.pu.go.id.

5. Badan Pusat Statistik Jakarta Pusat , 2017. Statistik Indonesia Tahun 2016. Jakarta Pusat: Badan Pusat Statistik.

6. Carmon, Naomi dan Gayrieli, Tamar. 1987. Improving Housing by Conventional Versus Self-help Methods: Evidence From Israel. Urban Study, 24 (4), 324-332, Agustus.

7. Direktorat Rumah Swadaya. 2016. Pengembangan Pelaksanaan Bantuan Rumah Swadaya. Kementerian Pekerjaan Umum dan Perumahan Rakyat Republik Indonesia: Jakarta

8. Huchzermeyer, M. \& Omenya, A. (eds). 2004. Housing Definitions for Republic of South Africa. Directorate of Policy and Programme Monitoring, National Department of Housing, Pretoria, South Africa 
9. Kementerian Perencanaan Pembangunan Nasional. 2014a. Rencana Pembangunan Jangka Menengah Nasional (RPJMN) 2015-2019: Buku I Agenda Pembangunan Nasional, Kementerian Perencanaan Pembangunan Nasional: Jakarta.

10. Ntema, Lejone John. 2011. Self-Help Housing in South Africa: Paradigms, Policy and Practice. Disertasi. Faculty of The Econodmic and Management Sciences (Centre for Development Support) University of the Free State, Bloemfontein, Afrika Selatan.

11. Mungkasa. 2011. Perumahan Swadaya Konsep, Pembelajaran dan Praktek Unggulan. Bappenas, Jakarta.

12. Pugh, C. 2001. The Theory and Practice of Housing Sector Development for Developing Countries, 1950-99. Housing Studies, 16(4), 399-423.

13. Sugiyono. 2009. Metode Penelitian Bisnis (Pendekatan Kuantitatif, Kualitatif, dan R\&D). Bandung: Alfabeta.

14. Turner, J.F.C. 1976. Housing by People. Towards Autonomy in Building Environments. Marion Byers, London. 